\title{
Determinants of Visitors' Expenditure Across a Portfolio of Events
}

António Manuel Martins de Almeida

University of Madeira

\section{Brian Garrod}

Swansea University

\begin{abstract}
Destinations are increasingly recognising the advantages of managing their calendar of events as a strategic portfolio. Currently, however, there is no accepted, workable and proven technique for identifying the most efficient variable(s) to employ as a basis for strategic intervention. This study develops a spare regression model, based on the LASSO method, to select an efficient subset of determinants of visitor expenditure across five annual events taking place in Madeira, Portugal. The results indicate that event attendees' income, length of stay and travel party size are significant determinants of total expenditure across all the events. Adopting strategic measures to influence these variables, if duly implemented at the portfolio level, can enable the cross-leveraging of additional expenditure that would be inaccessible to the destination if the event were acting independently of one another. This could, in turn, enable the destination to use it events efficiently to enhance its overall competitiveness.
\end{abstract}

Keywords: cross-leverage; destination; event; expenditure; portfolio; strategy. 


\section{Determinants of Visitors' Expenditure Across a Portfolio of Events}

\section{Introduction}

Events are a feature of most tourism destinations (Brida et al., 2013a; Clark and Misener, 2015; Lee et al., 2015). Events are often a long-established part of the fabric of community life in both urban and rural settings, and embody themes ranging from classical music to agriculture, sport to literature, and theatre to religion (Hjalager and Kwiatkowski, 2017; Kim et al., 2008). With event tourism recognised as one of the fastest-growing markets in the tourism industry (Smith and Costello, 2009; Ziakas, 2019), destinations are increasingly seeking to harness the various benefits that hosting events can bring. Many have therefore sought to grow their existing events, while others have developed new events, often adopting a broad theme in order to attract as wide as possible an audience (Antchack and Pernecky, 2017; Ziakas, 2019). Sometimes the new event is intended to supplement or complement the existing calendar of events; at other times the destination has been selected by the event organisers as a good place to stage it. In either case, events ranging from small-scale, community-based festivals to large-scale, commercial 'mega-events' are now an established part of the offer of many destinations worldwide (Buning et al., 2016; Ziakas and Costa, 2011).

Destination strategies have often focused on events based on the belief that they can achieve extensive positive media coverage, helping to enhance and spread the destination's image (Clark and Misener, 2015; Pereira et al., 2015; Tanford et al., 2012). Many destinations with a strongly seasonal pattern of demand have introduced new events to try to help 'fill in' the low season (Sainaghi et al., 2019). Indeed, events have the potential to diversify the offer and attract visitors who would not otherwise be travelling to the destination. There is also a common belief that developing a strong event offer can produce tangible benefits in terms of extended length of stay and greater daily expenditure (Buning et al., 2016; Lee et al., 2015). Previous studies suggest that tourists attending an event tend on average to have higher levels of expenditure compared with other tourists travelling to the destination (Brida et al., 2013b; Chang, 2006; Mortazavi, 2021; Pulido-Fernández and Sánchez-Rivero, 2010; Saayman and Saayman, 2006;). Destinations operating in mature destinations have, however, found it particularly difficult to "distinguish themselves in a crowded events marketplace” (Todd et al., 2017, p.11) and keep pace with global competition.

In this respect, destinations management organisations (DMOs) are increasingly recognising the potential to capture greater levels of visitor expenditure if they manage their events as a strategic portfolio (Lee et al., 2015; Ziakas and Getz, 2021). This, however, requires a thorough understanding of the factors that drive visitors' expenditure (Ziakas, 2014; Ziakas and Costa, 2011) in order to identify common drivers of expenditure among the various events in the portfolio. These areas of high relatedness can then be cross-leveraged in order to capture synergistic benefits that would not have otherwise been accessible to the destination (Pereira et al., 2015). There remains, however, a lack of empirical research into the determinants of visitors' expenditure across an event portfolio (Ziakas and Getz, 2021). Furthermore, the range and quality of data needed to apply the resulting models is frequently unavailable in practice (Getz and McConnell, 2014).

The purpose of this study is, therefore, to examine the determinants of spending in relation to a portfolio of five annually recurring events in Madeira, a mature destination on Europe's Atlantic periphery. As well as considering socio-demographic and trip-related variables, the study will examine the potential effect of attendance motivations and involvement (Ziakas 
and Costa, 2011), as well as whether attendees are travelling specifically for the event. The study will employ a spare regression method to identify commonalities in the determinants of expenditure among attendees of the five events. This would allow the DMO to apply a strategic portfolio approach to managing and further developing its events. In doing so, the study extends the current literature by simultaneously investigating five events taking place over the course of a single calendar year, based on fine-grained field data.

\section{Literature review}

The following literature review is divided into three sections. The first will consider the use of visitor's expenditure as a measure of event performance. The second will examine theoretical perspectives on managing events within a strategic portfolio to cross-leverage the synergies associated with exploiting areas of relatedness between them. The final section will then review the methods and findings of studies that have investigated the determinants of event visitors' expenditure, noting the general paucity of such work in the specific context of managing event portfolios in a strategic manner.

\subsection{Expenditure as a measure of event performance}

The planning, organising and funding of events remains one of the few areas of direct intervention by DMOs in terms of product development (Dredge and Whitford, 2011; Dredge and Jamal, 2015; Mariani and Giorgio, 2017; Phi et al., 2014). It is therefore a major financial and political commitment for many DMOs (Getz et al., 1998). With access to public funds increasingly under pressure, implying the need for greater accountability, transparency and efficiency (Gerritsen and van Olderen, 2020; Ziakas, 2020), interest has grown on the part of event organisers in obtaining scientific evidence on the quantifiable economic impacts of their events (Sharma et al., 2020). This can assist DMOs in gaining the public support they need to justify the investments they are making (Catlin et al., 2015; Linberg and Fredman, 2015; Tyrrell and Johnston, 2006; Wood and Glasson, 2006).

Events are expected to earn a return on investment by bringing more money into the destination economy (Antchak, 2017; Gerritsen and van Olderen, 2020; Hjalager and Kwiatkowski, 2017). Perhaps not surprisingly, therefore, the economic imperative has tended to govern the design, conception, production and communication of events (Lindberg and Fredman, 2015) and, in many instances, has been the primary policy goal (Sharma et al., 2020). As such, event tourism has tended to be viewed as essentially an expenditure-driven activity (Eugenio-Martin and Inchausi-Sintes, 2016; Hung et al., 2012; Jingwen and Mingzhu, 2018, Marrocu et al., 2015), with the magnitude and pattern of visitors' expenditure largely conditioning the nature of the economic impacts associated with the events concerned (Wicker et al., 2012).

Previous research has duly focused on practical ways to increase visitors' expenditure (Cárdenas-García, 2012; Pulido-Fernandès et al., 2016). Catlin et al. (2015) and Mihalic (2002) consider knowledge of the determinants or drivers of expenditure to be central in understanding the economic impacts of events. The determinants of visitors' expenditure have, accordingly, often been a subject of investigation (Brida et al., 2013a; Brida et al., 2018). The majority of such research has, however, been based on single case studies, often in the context of sporting events (Alegre and Cladera, 2010; Buning and Gibson, 2015; Godbey and Graefe, 1991; Kim et al., 2010; Lew and Ng, 2012; Lee et al., 2015; Oppermann, 1996; Wang et al., 2006).

\subsection{Event portfolios and the cross-leveraging of benefits}

More recently, interest has grown among events managers in the potential for crossleveraging additional benefits by managing their events as a strategic portfolio (Ziakas, 2014, 
2020; Ziakas and Getz, 2021). According to Clark and Misener (2015, p.13) an event portfolio is "a series of interrelated events in terms of resources, theming, and markets, which are strategically positioned on the basis of their operational and thematic relatedness". This means that an event portfolio is more than simply "a coincidental collection of events within a destination" (Viol et al., 2018, p.248) or even one that has been assembled purposefully to fill in gaps in a destination's events calendar, perhaps to address problems of seasonality in demand.

Obtaining synergises implies "achieving more benefits [from the event portfolio] than the sum generated individually” (Pereira et al., 2015, p.30). The concepts of relatedness and cross-leverage are important in this regard. Relatedness determines the event portfolio manager's ability to apply common strategies for the different events in the events in the portfolio by implementing cross-cutting initiatives. These might include, for example, developing new niche market, transferring knowledge and best practices from one event to others in the portfolio, sharing resources and image-building (Pereira et al., 2015; Ziakas and Costa, 2011). A unifying theme for the events is often adopted in order to assist in programme planning (Ziakas and Costa, 2011) Specific tactics that could be employed include, for example, product-service bundling, joint-marketing initiatives, cross-promotion and co-branding (Ziakas, 2014, 2020).

Cross-leverage, meanwhile, can be considered a means of "ensuring maximum gain from an event” (Kelly and Fairley, 2018, p.335). It requires event managers to devise and implement strategies that will harness the relatedness between the events in the portfolio, making efficient use of its inevitably limited resources to achieve the goals that have been set for them (Chalip, 2004; O’Brien, 2007; O’Brien and Chalip, 2008). As such, cross-leverage means making "optimal use of resources in the provision that each event in the portfolio complements or reinforces the benefits bestowed by other events" (Ziakas, 2020, p.2).

The success of relatedness and cross-leverage strategies clearly depends on the initiatives being used. This, in turn, requires event organisers to implement monitoring processes to collect and analyse the data they need to identify underlying trends in the determinants of their measures of success (Baade and Matheson, 2002; Chalip, 2014; Chalip and Leyns, 2002; Pennington-Gray and Holdnak, 2002). Many events do not, however, routinely collect data with the regularity, quantity of quality required. Managing a destination's events as a strategic portfolio is often therefore confounded in practice by a lack of data (Wicker et al., 2012). Destinations have rarely been able to take advantage of a large database that can be divided into sub-samples pertaining to single events. Little is known, therefore, about the overall pattern of expenditure of events managed together as a portfolio, despite persistent calls for more research to be undertaken on the subject (Hjalager and Kwiatkowski, 2017; Pereira et al., 2015; Wicker, et al., 2012).

There also remains a dearth of research on the process of strategically developing and managing an event portfolio (Dickson et al., 2018). Indeed, Antchak (2017) observes that most studies to date have focused on theoretical perspectives that explain the additional benefits that can be obtained by managing events in a portfolio. Ziakas and Getz (2021), meanwhile, indicate that event portfolio management is still an emerging field, both in theory and practice. Compared with the multitude of studies of single events, only a small number of studies have examined the cross-leveraging across the context of an event portfolio (Dickson et al., 2018; Todd et al., 2017; Ziakas and Costa, 2011). It will also invariably be the case that the DMO will need to co-ordinate the efforts of a wide range of destination stakeholders, including both large and small business, tourism agencies, local business associations, government economic development agencies and institutions, and individual event organisers 
Ziakas (2020). The destination context therefore tends to further complicate an already very challenging task.

\subsection{Determinants of event visitors' expenditure}

The empirical evidence related to event visitors' expenditure that is needed to guide DMOs in developing cross-leveraging strategies has been described patchy and frequently inconclusive (Lee et al., 2015). There are some lessons to be learned, however, from the general tourism literature. Many studies in the general tourism context have, indeed, suggested that sociodemographic variables tend to exert a substantial influence on expenditure patterns. Wicker et al. (2012), for example, notes that age had a positive effect on expenditure in a number of studies, with older participants more inclined to spend than younger ones. Brida and Scuderi (2013), meanwhile, conducted a meta-analysis of 190 regression models and found that 61 of 87 cases implied a positive impact of age on expenditure, whereas 26 had a negative relationship. In the other 103 cases, the coefficient was found not to be statistically significant.

Income has been extensively studied as an explanatory variable in general tourism studies, with a positive relationship between income and expenditure being well established (Jang and Ham, 2009). In their meta-analysis of events studies using regression models, Brida and Scuderi (2013) found that in 148 of 163 cases, income impacted positively and significantly expenditure, with only nine cases of a negative and statistically significant relationship. Access to greater financial resources allows participants to stay at luxury hotels, opt for highend restaurants and adopt means of transport such as hire cars, all of which tends to increase their expenditure (Wicker et al., 2012; Jones et al., 2009).

Nationality is also frequently found to have an important impact on expenditure in general tourism studies, with international tourists consistently spending more than national tourists or locals (Jones et al., 2009; Saayman and Saayman, 2006; Wood et al., 2006). Education and professional status have been found to impact positively on expenditure, whereas travelling with children is often found to impact negatively (Cannon and Ford, 2002; Jones et al., 2009). Cai et al. (1995) found that general tourists' expenditure can be influenced by the number of children in the party and marital status. Wang and Davidson (2010) and Brida and Scuderi (2013), meanwhile, suggest that the literature indicates that gender is not a significant determinant of tourist spending.

Travel arrangements and visit motivations have also been extensively analysed as determinants of expenditure among general tourists (Cai, 1998, 1999; Cai et al., 1995; Jang et al., 2002, 2004; Oppermann, 1996; Seiler et al., 2002). Others have examined variables such as length of stay, accommodation type, travel party size, travel distance and 'context-related variables' (e.g. type of destination and activities undertaken) (Thrane and Farstad, 2011; Jones et al., 2009). Thrane (2014) found out that variables such as the type of destination (urban or rural), mode of transportation and trip purpose all had a statistically significant impact on tourists' expenditure.

With regard to events in particular, two variables emerge from the literature as being frequently decisive: motivation to attend and repeat visits. Motivation is often assumed to have a positive effect on expenditure because participants travelling specifically to attend the event are expected be more involved in it and therefore to spend more. Many studies do indeed suggest that tourists whose primary motivation is to attend an event spend more than average, usually by staying longer and travelling with a large group (Kelly and Fairley, 2018; Gibson et al., 2003; Tang and Turco, 2001; Yoon et al., 2010). However, several studies of sporting events (Ritchie et al., 2002; Sato et al., 2014) suggest that visitors driven by dual 
motivations (i.e. other tourism activities as well as attending the event) tend to spend more compared with participants whose interest is solely in the sport event.

The available research also shows that tourists participating in cultural visits within the destination have higher levels of consumption than other tourists, which leads to a higher level of expenditure in the destination (Brida et al., 2013b; Chen et al., 2010; PulidoFernández and Sánchez-Rivero, 2010). Saayman and Saayman (2006), and Pulido-Fernández and Sánchez-Rivero (2010), among others, have shown that tourists who visit a cultural urban setting and seize the moment to attend an event being held in area report higher-than-average levels of expenditure. With regard to the impact of repeat visits on the level of expenditure, the evidence available is mixed, failing to "offer a readily generalizable explanation on the effect of repeat attendance on visitor expenditure patterns” (Lee et al., 2015, p.178). A number of studies on general consumers' expenditure indicate that spending decreases with repeat purchasing, so that Petrick (2004a; b) considers it unwise to assume that increased levels of repeat visitation represents to an advantage to the destination (Alegre and Cladera, 2010; Chang et al., 2013; Lehto et al., 2004). Some studies do indeed suggest that repeat visitors spend less compared to first-time visitors and are more price sensitive (Alegre and Juaneda, 2006; Oppermann, 1997; Jang et al., 2004). Repeat visitors can "behave more efficiently" (Alegre and Caldera, 2010, p. 518), such as by knowing how to find cheaper alternative and avoid being overcharged, based on their previous experience. A number of studies have, however, failed to identify statistically significant differences between first-time visitors and repeat visitors in terms of their total expenditure (Oppermann and Chon, 1997; Mok and Iverson, 2000; Wang et al., 2006; Chang et al., 2013).

The literature reveals a complex picture in terms of the link between travel motivation to undertake particular activities on general tourists' expenditure, with studies often revealing no significant effect (Brida and Scuderi, 2013). With regard to events specifically, Buning et al. (2016) found that when travel parties included more participants (as opposed to accompanying persons) in a sporting event, daily expenditure per person was accordingly higher. Smith and Costello (2009) found a similar result with regards to food enthusiasts and casual event attendees at a food festival. Lee and Taylor (2005) found that spectators of a sports event spent more than other tourists, albeit largely because of the high stadium admission prices. Sato et al. (2014) found that while event participants were more likely to spend money on accommodation, they were not likely to spend more on non-event related activities. This suggests that 'involvement' may be more important than motivation in determining visitor's expenditure, although this expenditure is likely to be associated with the event itself rather than activities in the wider destination.

\section{Context}

The events in his study all took place in Madeira from early 2017 to early 2018, and included the Carnival (February), Flower Festival (May), Atlantic Festival (July), Wine Festival (September) and Christmas and New Year's Eve festivities (December and January). A summary of the key characteristics of each event is presented in Table 1. The Regional Directorate for Tourism (DRT), which serves as Madeira's DMO, does not routinely keep track of the number of attendees at any of these public, mostly outdoor, open-space events. The number of the total number of attendees, in the tens of thousands, has therefore been estimated for the purpose of this study based on hotel occupancy released by the Statistical Office. The events represent an important drawcard to the destination, which is an autonomous region of Portugal, helping to give it a recognisable brand and a unique selling point with respect to competitors. Events are expected to play a major role in the future growth of Madeira's tourism sector particularly by attracting new tourists to the island who 
would not otherwise have visited, particularly during the 'low' tourist season when hotel occupancy rates tend to be lower (Ruggieri, 2015). The data on hotel occupancy does indeed suggest that festival organisers have so far been able to attract large crowds, with many visitors travelling with the sole purpose of celebrating the event.

** Table 1 near here **

The greater degree of importance accorded to the events sector in Madeira is relatively recent. Since the 1990s, but more particularly after 2010, Madeira's Regional Government adopted a number of initiatives aimed at increasing the number of cultural events on offer. As well as to attract more visitors, from new segments, the aim is also to increase the cultural and experiential value added of current product by providing a variety of experiences for visitors. As such, and as elsewhere, Madeira's festivals have been developed in order to address a broad range of goals (e.g. community development, preservation of local heritage, provision of leisure opportunities), although one of most decisive objective relates to positive economic outcomes deriving from a greater number of tourists visiting the destination.

As in many other world destinations, some of these events are reproductions of traditional festivals that have been taken by event managers and commercialised with the intention of attracting tourists (Brida et al., 2013a). Madeira is also no different to many other world destinations insofar as some of these festivals were formally rural in nature and have been drawn into urban settings (McCartney and Osti, 2007). In Madeira's case, this has involved the events being staged in the capital city, Funchal.

A number of parallels can thus be drawn between these five main events in Madeira's event portfolio that embody relatedness that could potentially be harnessed. Indeed, all of the events are deeply rooted in Madeira's cultural traditions and identity, take place in public spaces, are entertainment oriented and target international tourists. Meanwhile, each event is distinguished through its specific theme, attendee profiles, origins and reputation on the international market. While Madeira has hosted a number of sporting events in the past (including an ultra-marathon), none of those in its portfolio are concerned with either spectator or participation sports. As such, it can be argued that Madeira attempts trade mainly on its proven strengths, including its rich agricultural traditions, unique Atlantic location and warm year-round climate, friendly and safe reputation, and slower pace of life. It should be noted, however, that while Madeira's DMO has been assigned the task of managing the events, it is still in the process of attempting to identify an efficient strategic approach for cross-leveraging additional benefits from the portfolio as a whole.

\section{Methodology}

This analysis presented in this study focuses on tourists participating in the five main events staged in Madeira from February 2017 to January 2018. The sample comprises foreign tourists and Portuguese nationals from the mainland. Some were travelling specifically to attend the festival but, for many tourists, attending the festival was not the primary reason for their visit. The questions were developed from previously validated surveys (Buning et al., 2016; White and Stynes, 2008) and inputs from representatives of the DMO.

The first draft of the questionnaire was revised by an expert in order to identify any issues relating to wording, clarity, measurement and content validity. The questionnaire was then pilot tested among international hotel guests and tourists waiting for flights at the airport in order to check for clarity of wording and to determine the amount of time participants would need to complete it. Following some minor amendments, the final draft was reviewed by the research team to identify any additional problems in terms of format. The questionnaire was made available in four languages (Portuguese, English, German and French). The final 
version comprised four sections aimed at collecting data on (i) socio-demographic characteristics (including age, gender, income, civil status, education and nationality), (ii) travel arrangements (including length of stay, party size, whether this was their first visit to Madeira), (iii) motivations (including previous knowledge of the event, information sources used and whether this had influence their decision to visit Madeira) and (iv) event-related variables (including expenditure, participation, satisfaction with the event they were attending and willingness to recommend). Given the likely importance of involvement noted in the literature review, the study differentiated between visitors travelling with the sole purpose of participating in the event and other tourists attending by chance. Their expenditures were attributed to the event whatever their motivation to attend it and their degree of behavioural involvement (Catlin et al., 2015).

In view of the limited window of time available to encounter event attendees, as well as the generally open-air nature of the events (Mortazavi, 2021), a non-probability sampling method was adopted (Brida et al., 2013c; Smith and Costello, 2009; Thibaut et al., 2016; Wicker et al., 2012) and two different means of distributing the survey were used (Catlin et al., 2015; Silva et al., 2020). First, managers and owners of different types of tourist accommodation establishments (three-star, four-star, five-star, aparthotels, luxury hotels, etc) were asked to participate in the study. Those who accepted were asked to give a copy of the questionnaire to their guests. Second, the questionnaire was distributed to tourists leaving Madeira at the airport. The survey was in both cases self-administered. The main advantage of this method of data collection is that it enabled a relatively large dataset to be collected; the main disadvantage is that it may not be wholly representative of the population from which it is drawn (even if this were known).

The data analysis was carried via SPSS 25.0 and STATA 16 . The five datasets $(C(n=598)$, FF ( $n=622)$, AF ( $n=665)$, WF $(n=337)$ and CF $(n=896))$ were first combined in one larger dataset. Basic descriptive statistics were then calculated to obtain an overview of the data based on means and frequencies. Dummy variables were defined for country of origin, academic background and each of the five events. Based on Brida and Scuderi (2013), dummy variables were also included relating to opinions and complaints made in the open section of the questionnaire. A list of the variables under analysis, along with some descriptive statistics, is included in Table 2. The explanatory variables are subdivided into four major categories: socio-economic, travel-related, motivational, and event-related variables (Marrocu et al., 2015; Wang et al., 2006).

** Table 2 near here **

The analysis of the data was conducted in two stages. The survey produced a large number of theoretically valid determinants of expenditure in order to increase the likelihood of finding commonalities between them. The first step was, therefore, to narrow down the pool of candidates in order to identify a more parsimonious model (Brida et al., 2018; Grasgruber et al., 2016). The aim of this first stage was thus to identify a model with high predictive power that picks out "the most important regressors from the less vital ones" (Thrane, 2015, p. 66). It was also deemed important to develop a model for which the results would be easily interpretable by decision makers (Pulido-Fernández et al., 2016).

Various procedures have been used to handle datasets containing a large number of independent variables, including ridge regression (Assaf et al., 2019; Matijová et al., 2019), LASSO regression (e.g. Guo et al., 2015; Hammami et al., 2012; Tibshirani, 1996) and elastic net regression (Abbruzzo et al., 2014; Matijová et al., 2019). These methods are all based on the 'penalisation' (artificial lowering) of beta regression coefficients and are considered ideal to handle explanatory variables characterised by high levels of 
multicollinearity, while also being an effective means of variable selection through the detection of significant predictors from an initial pool of candidate variables (Guo et al., 2015). LASSO is considered to be particularly well-suited to handle such high-dimensional models, which are becoming increasingly more predominant in the field of tourism due to greater data availability, since it permits the identification of the more efficient predictors from a large potential pool of covariates (Oloritun et al., 2013). As observed by Silveira et al. (2018, p.1320) "the introduction of a penalization reduces the variability of the estimate, thereby improving the accuracy of prediction ... besides automatically eliminating the irrelevant variables".

Such 'shrinkage' methods can, moreover, be understood to be an extension of OLS regression, which offers advantages in terms of the interpretation of the coefficients (Anda et al., 2018; Grasgruber et al., 2016). LASSO commands in STATA also provide practical tools to produce inferences on a few key variables of interest. For these reasons, the present study opted for LASSO regression, as developed by Tibshirani (1996). A detailed description of the LASSO procedure can be found in Friedman (2001) and in Elith et al. (2008). While previous studies have employed methods such as forward stepwise and backward stepwise selection, Hammami et al. (2012) observe that the LASSO has shown to be a more effective procedure in comparison to stepwise algorithms. In this study, equivalent OLS and Tobit models were computed to allow comparisons to be made with regard to model selection.

In the second stage, the variables identified above were employed to determine their impact on expenditure on each of the five events. Most analysis on the determinants of expenditure are based on a priori judgments informed by a review of the literature. In this study, only the variables identified the first stage were employed in the second stage of the analysis, which employed both OLS and Tobit analysis to facilitate comparison and enable a fuller picture to be obtained. Several different econometric methods have been employed by researchers examining the drivers of tourist expenditure (Brida and Scuderi, 2013; García-Sánchez et al., 2013; Lee et al., 2015). Because it is virtually impossible to visit Madeira as a tourist without incurring some expenditure, the dependent variable in this study is necessarily non-zero. It has widely been argued in the literature that in such circumstances, ordinary least squares (OLS) regression is inappropriate (Hung et al., 2012; Salgado-Barandela et al., 2018; Sharma et al., 2020; Thrane, 2015; Santos and Vieira, 2012; Wu et al., 2013), although a large number of papers still rely on OLS (Brida and Scuderi, 2013). One of the most frequently employed econometric methods has, therefore, been the Tobit model (Barquet et al., 2011; Brida et al., 2013; Buning et al., 2016; Disegna and Osti, 2016) which, as a censored method, is considered to be better suited to handling dependent variables constrained by both lower and upper limits.

\section{Results}

The sample comprised 3118 respondents in total, of which attendance was at the Carnival (19.2\%), the Flower Festival (19.9\%), the Atlantic Festival (21.3\%), the Wine Festival (10.3\%) and the Christmas and New Year festivities (28.7\%). The profile of visitors across the events as a whole by origin country was Britain (27\%), Germany (23\%), the Portuguese mainland (14\%), France (13\%) and other countries (24\%).

The gender split of the total sample was almost even, and the average age was 58, with most respondents in the 65 or older (33.8\%) and 55-64 (27.2\%) age groups. Around 54.4\% of the sample held at least an undergraduate degree. Average monthly income was €3531 and almost one third (31.2\%) of the sample earned less than $€ 2000$. Only a small minority of the respondents (5.5\%) earned more than $€ 7500$. The results of the demographic analysis thus suggest that respondents share a number of common characteristics with tourist travelling to 
Madeira in general, although the current average age of 58 is clearly higher than the average of 44-50 for general tourists to Madeira reported by others (Correia et al., 2018).

A closer look at the output also reveals significant differences in average expenditure between the events. The average for the whole sample was €2795 per person but the figures for the Carnival (taking place before Easter), Flower Festival (taking place after Easter), Atlantic Festival (June), Wine Festival (September) and the Christmas and New Year festivities were $€ 2612$, €2933, €2700, €2538 and €2996 respectively. It can be seen, therefore, that average expenditure did not vary consistently over the course of the year. Similar differences can be noted in the case of purpose of visit to Madeira, with only $26 \%$ reporting that they were travelling specifically to take part in the main event. Event attendees, meanwhile, reported consistently high levels of satisfaction, averaging 6 on seven-point scale. As such it can be argued that the events do supplement the destination's appeal, but their appeal is not yet sufficient to attract a large additional number of tourists to visit (Smith and Costello, 2009; Quan and Wang, 2004). This may be because the strategy of managing them as a portfolio has not yet been fully embraced, which implies that there are likely to be substantial additional benefits to be cross-leveraged in doing so.

Table 3 demonstrates that expenditure was not significantly influenced by most of the sociodemographic variables, while the opposite was true of many travel- and event-related variables. Visitors travelling with the sole purpose of attending the event tended to spend more on average than those attending by chance (€2872 vs. €2767), but the differences are not statistically significant ( $\mathrm{t}=-\mathrm{1.331}$; sig=0.183). There were, however, statistically significant differences with regard to past participation in an event (62\% vs. 38\%; $\left.\chi^{2}=127.040 ; \operatorname{sig}=0.000\right)$ and previous visits to the destination $\left(69 \%\right.$ vs. $31 \% ; \chi^{2}=115.043$; sig $=0.000$ ). Those attendees who declared themselves highly satisfied reported above-average levels of expenditure ( $€ 2937$ vs. $€ 2704$; $t=-3.199$; sig=0.001) but previous participants in an event reported lower expenditure ( $€ 2757$ vs $€ 2958$; $\mathrm{t}=2.204$; sig=0.028).

** Table 3 near here **

Consistent with standard procedure in LASSO, 22 of the initial pool of 50 variables were selected for further analysis based on the cross-validation (CV) selection procedure (for further details, see STATA, 2019). The adaptive and the plug-in methods, in contrast, selected 17 and six variables respectively. As the CV method performed slightly better in terms of out-of-sample prediction $\left(\mathrm{R}^{2}=0.2236\right.$ vs. $\mathrm{R}^{2}=0.2200$ vs $\left.\mathrm{R}^{2}=0.2033\right)$, however, the analysis proceeded on the basis on the CV method (See Table 4).

** Table 4 near here **

The results from the CV-based LASSO regression included the following explanatory variables: socio-demographic (age, academic background (secondary and undergraduate); civil status (single); country of origin (Portuguese mainland and 'Other')); economic (income); travel-related (first visit; length of stay; type of accommodation (three stars, five stars and 'other', i.e. local lodging); travelling with children; and booking through travel agency)); and event-related (satisfaction, positive feedback; feedback; participation in other activities; type of event (the Carnival; the Flower Festival and the Christmas and New Year festivities)).

These results are shown in Table 5. For purposes of comparison, the table also provides outputs for the corresponding OLS and Tobit methods, which would appear to be equally robust. Some interesting similarities and differences nevertheless emerge. The results of all three models indicate that the propensity to spend is significantly influenced by income, travel party size and duration of stay. Every increase of $€ 1000$ in the level of income results 
in an increase of $€ 290$ in terms of total expenditure (on average, across the full sample). The positive impact of booking through a travel agent also emerges as statistically significant. The results indicate that the impact of travel party size is positive and statistically significant, which is also consistent with expectations (Lawson, 1994; Wang et al., 2006).

** Table 5 near here **

As anticipated, the standard of accommodation was found to be an important determinant of expenditure, with a strong positive impact with respect to staying in a five-star hotel (Carlsen and Woods, 2004; Catlin et al., 2015). The sign of the coefficient for local lodging was, in contrast, negative. It might be expected that respondents opting for cheaper accommodation would spend more in the destination, because savings in cheap accommodation would release their budget to allow them to make other types of expenditure. This did not seem be the case in this study, however, as visitors staying in lower-quality accommodation spent significantly less than the average ( $€ 2217.1$ vs. $€ 2870.8$; $t=6.0872$; sig=0.000). Opting for a local lodging also led to a reduction in total expenditure equivalent to $11.9 \%$ of the average computed across the whole sample. In this regard, the development of the local lodging sector can be considered to be a matter of common concern for both government and the tourism sector as further growth of this sector will lead to a decreasing level of expenditure.

Consistent with previous studies (Brida and Scuderi, 2013; Masiero and Nicolau, 2012), nationality was also found to be important. Those travelling from the Portuguese mainland spent less than the average, as indicated by the negative coefficient. Studies by Mortazavi (2021), Saayman et al. (2005) and Marrocu et al. (2015) also found that domestic visitors tend to spend less than international ones. This might suggest that events managers should focus on attracting more international (i.e. non-Portuguese) visitors. It should be noted, however, that at a more detailed level, the lower expenditure of Portuguese nationals was only evident among those attending the Flower Festival. Furthermore, as Portuguese nationals are less costly to reach with marketing campaigns, and more likely to return to the destination, the wisdom of trying to refocus efforts to attract visitors away from Portuguese nationals may be not as clear cut.

Table 6 reports the sign and statistical significance of the coefficients associated with the variables identified in Table 5 with respect to each event. In contrast with standard procedure, and in line with Marcussen (2011), no logarithmic transformations were used with the dependent variable. This has the advantage of the regression coefficients being directly and easily interpretable in terms of the impact of discrete or marginal changes of the explanatory variables on total expenditure. The results indicate that a number of variables were consistently highlighted in all five events as being significant determinants of expenditure, regardless of whether OLS and Tobit analysis was employed.

** Table 6 near here **

As previously noted, the variable relating to the visitor's motivation to attend was not selected in the first stage of the LASSO. A number of arrangements and event-related variables did, nevertheless, prove statistically significant at this stage. For example, satisfaction was found to have a positive impact on total expenditure. The non-LASSO model using OLS, based on the entire sample, indicated that the coefficient of this variable was not statistically significant. These results contradict previous studies (Dearden et al., 2006; Jones et al., 2009; Kim et al., 2008; Sato et al., 2014; Thrane, 2002; Wicker et al., 2012). The table also shows that motivation was not statistically significant as a determinant of expenditure in three out of the five events. Where it was statistically significant, the coefficient was negative, which is contrary to expectations (the level of expenditure would normally be 
expected to increase if the respondent has travelled with the express purpose of attending the event).

A key aspect of the results is the number of variables that were not statistically relevant in any of the models. These included first visit, feedback, participation in other events and academic qualifications (secondary level). Wang et al. (2006), Wang and Davidson (2010) reported similar findings. With regard to education, Brida and Scuderi (2013) noted that this was a significant determinant in only 97 of the 222 studies included in their meta-analysis. For the sample as whole, satisfaction was found to impact expenditure, which is consistent with studies by Chen and Chang (2012), Chhabra et al. (2002), Kim et al. (2010) and Kozak et al. (2008), which found that satisfaction with the overall stay or with some aspects of it, resulted in higher levels of expenditure. In the present study, however, satisfaction was found to impact expenditure at just one of the five events.

In line with previous studies (Brida and Scuderi, 2013; Jang et al., 2004; Mortazavi, 2021; Sato et al., 2014; Tang and Turco, 2001; Thrane, 2016) income, travel party size and length of stay impacted positively on total expenditure at each of the five events. Staying in threestar and five-star accommodation also emerged as statistically significant in three out of five models, although with differing signs, which accords with previous studies (notably Brida et al., (2013a,b,c; Marcussen, 2011; Mortazavi, 2021; Thrane, 2015). In overall terms, the most relevant determinants of expenditure related to travel-related variables, such as travel party size and length of stay. Previous studies have also reached the conclusion that trip-related variables tend to be important determinants of tourism expenditure (Thrane, 2015). Economic factors (proxied by income and, to a certain extent, by type of accommodation) also appear to play a decisive role in predicting expenditure in this study, which is consistent with the results of studies by Salgado-Barandela et al. (2018), Mortazavi (2021) and Wicker et al. (2012). As such, certain variables would seem to be demonstrably more decisive than others in determining visitor's expenditure, depending on the event under consideration.

\section{Discussion}

The comparative analysis of events in Madeira's event portfolio presented here identifies a number of variables that correspond to possible areas of relatedness which, if appropriately exploited, could permit the DMO to cross-leverage additional expenditure from the portfolio. Before proceeding, it should be noted that the findings include some unexpected results. For example, several socio-demographic variables were excluded at the first stage. The only variables relating to nationality with statistically significant coefficients were mainland Portugal and 'other countries'. Moreover, variables such as gender, civil status and academic background did not significantly influence attendees' expenditure. This is not what previous studies of individual events has normally found. In this multi-event study, in contrast, expenditure is determined mainly by income and travel-related variables, which means that overall spending pattern is mainly driven by decisions taken by visitors, based on criteria such as purchasing power, accommodation attributes and disposable income. This suggests that the DMO should move away from traditional geographic and socio-demographic market segmentation and embrace the potential for behavioural and psychographic market segmentation.

Several variables were consistently found not to be significant determinants of expenditure across the five events. These included whether this was the attendee's first visit to the destination, which appears not to be relevant to visitors' expenditure decisions, as well as previous participation in the event attended. It should be remembered, however, that it may be that these variables were excluded from the analysis not because they are theoretically 
irrelevant but simply because they were not selected by the algorithm owing to a number of other stronger determinants being available instead (Silveira et al., 2018).

With regard to the variables where there do appear to be commonalities across the portfolio, the results indicated that length of stay was a significant determinant of total expenditure with respect to all five events. Given that extending the length of stay gives destination visitors more time and opportunity to spend, this is not an unsurprising result but it is important to bear in mind the more important finding this effect to be common across all five events, making it a promising variable for the cross-leveraging of expenditure. Strategic intervention, co-ordinated by the DMO, could therefore include measures such as providing discounts on accommodation (particularly during the low season when the accommodation stock is not fully utilised) and the bundling of event attendance with an extended stay to enjoy the attractions of the wider destinations. Developing more opportunities for visitors to make impulse purchases might also be worthwhile (Meng and $\mathrm{Xu}, 2012$ ). As noted above, strategic marketing programmes might consider the non-Portuguese market to be efficient targets as they tend to spend more than Portuguese visitors. This is in direct opposition with the current DMO marketing strategy, however, which is directed at encouraging mainlanders to visit Madeira, depicting the regional is Portugal's own 'tropical paradise'.

A second variable of interest is income, which was a significant determinant of expenditure in the case of all five events. This is not entirely surprising, since income and expenditure are always likely to be highly correlated (although not entirely if borrowing takes place). In practical terms, however, it does serve to suggest that an appropriate cross-leveraging strategy could involve target marketing to people with higher incomes. The point of departure in this study is that this appears to be true of all the events, so if the strategy works for one event it should work for them all. Interventions such as co-branding, joint marketing and so forth might, therefore, serve to cross-leverage additional expenditure from the event portfolio as a whole. The data suggest that older visitors and those from outside of Portugal, are likely to be the best market segments to target in this respect. In looking to the future, the DMO could also consider developing a new festival to slot into the calendar of events that is designed specially to appeal to the older generation. This could, for example, focus on Madeira' cultural heritage or culinary traditions: themes that have a proven appeal to older and wealthier tourists.

Third, travel party size was shown to be a significant determinant of overall expenditure in the case of all five events. Again, while this may not seem to be surprising finding itself, the point is that this effect is consistent across the entire event portfolio. Travel party size thus indicates another area of relatedness between the events which, if the events are managed as a portfolio, might potentially be cross-leveraged to bring additional expenditure to the destination. This is expenditure that could not be accessed by managing the events independently: it can only be captured by managing them as a strategic portfolio. One way to achieve this might be to encourage other party members to undertake other activities in the destination while the event is taking place but other results from the study suggest that this may not be an effective strategy. Contrary to expectations, respondents who participated in other activities, not associated with the event, tended to exhibit lower levels of expenditure. Research undertaken in other contexts, meanwhile, suggests that the degree of involvement in activities is correlated positively to expenditure (Jones et al., 2009; Wood et al., 2006). This suggests that the DMO would do better to encourage all the party members to attend the event - or at least sub-events on the fringe of the main event - and to ensure that there are amply secondary-spending opportunities to capture their attention and expenditure.

\section{Conclusions}


While the results of the analysis of the dataset as a whole are generally in line with previous studies, this study contributes important new knowledge by demonstrating where the determinants of event visitors' expenditure significantly overlap across all five of the events in Madeira's portfolio. These are important insights, as the strategic co-ordination of strategies intended to capture visitor spending across the five events will enable additional expenditure to be unlocked that would not otherwise be accessible. Putting this another way, even if the five events were able to maximise their visitors' expenditures individually, the total expenditure across the five events would not be as high as the amount that could be gained by adopting a co-ordinated strategy across all of them. These are additional, synergistic benefits that only the use of strategic portfolio approach can hope to unlock.

The following example may help to explain this important outcome. If, on the one hand, the five events were to operate in isolation, one variable that would be a good candidate as a means to increase visitor expenditure would be to promote the use of three-star hotels by event attendees. This could be achieved, for example, through the use of co-branding or the strategic bundling or event tickets with three-star accommodation establishments. The use of three-star accommodation is, however, only significantly related to an increase in expenditure in the case of three of the five festivals, so if the same strategies were employed at the other two festivals, they would likely have little impact (or even be counter-productive). If, on the other hand, all five events were to co-ordinate their strategy, focusing on one of the areas they have in common (e.g. targeting high-income visitors), the effect would be to generate more expenditure across the portfolio as a whole than the sum of expenditure that could be earned by the five events working in isolation.

One way in which visitors with higher incomes could be attracted, which is supported by the findings of this study, is to target older people in the destination's marketing strategies. This relationship, which is found in other studies of events in Madeira and elsewhere, is ascribed to the tendency for older people to have higher disposable incomes and thus more spending power. The results of the study also suggest that older people tend to stay longer in the destination. Again, this finding is consistent with previous studies, the argument being that older people typically have more free time and the flexibility to take longer trips.

Strategically targeting older visitors across all five events may thus be an effective crossleveraging strategy for Madeira's event portfolio. Co-ordinating such a strategy will inevitably fall to the DMO, but Madeira can be considered fortunate that the DRT is well established and is able to command the confidence of a wide range of destination stakeholders. This, of course, does not mean that the individual event organisers and the breadth of tourism businesses in the destination will not need to find effective ways to cooperate with one another.

Indeed, one of the strategic measures that was identified in the study would be to ensure that convenient, reliable and cost-effective transportation is made available to enable older people to travel from their hotels to the city centre where the events take place. While Funchal is a relatively small city, and walking is an option for most people, many older people would find the journey difficult, particularly when staying in the budget hotels that tend to be on the urban periphery. This would especially be the case for those who have limited mobility, so an effective strategy might be to ensure that additional buses are timetabled for when the events are running, to adapt the bus routes to include more hotels, to make bus trips free to older people, to run special coaches from the hotels to the city centre, or even to form a strategic partnership with taxi companies to enable discounts to be offered to older people.

Another destination-level strategy could be to ensure that visitors are encouraged to join in with other secondary events, rather than to focus simply on the main one. The data suggest 
that doing so is associated with staying longer in the destination, which is itself positively related to visitor expenditure. As well as through ticket sales, another way to harness this additional expenditure could be to make sure there are more secondary-spending opportunities, for example the purchase of street food or souvenirs. However, event organisers must be careful to avoid harassing tourists because such behaviour is thought likely to be counterproductive (Alrawadieh et al., 2019).

Looking beyond the immediate case this study of Madeira's events, a number of observations can be made about the essential differences between taking a portfolio approach to the strategic management of an event portfolio and considering each event in the calendar independently of the others. Foremost among these, as noted above, is the potential for the portfolio approach to enable additional, synergistic benefits to be cross-leveraged. These are benefits (in this case, visitor expenditure) that could simply not be accessed without the adoption of a strategic portfolio management approach.

Other advantages of adopting the portfolio have also been noted in the literature. Events can function as an extension of existing destination branding, helping to supplement it and make it more powerful (Chalip and Costa, 2005; Pereira et al., 2015). Events can be used to help reposition and re-brand the destination based on its cultural, heritage and historical resources (Ziakas, 2020). They can help to combat the problem of seasonality that many destinations face. Events can also serve as a catalyst to attain environmental aims and to support the cultural traditions of the destination. Indeed, festivals are considered to be a powerful communication tool in this respect (Chang, 2006). The establishment of 'sub-events' within an event can be a good way of promoting specific aspects of the local culture.

Ferdinand and Williams (2013) recommend the creation of a depository of eventmanagement experiences and best practices to assist event organisers in designing and staging events so that they can better achieve their stated aims. This study suggests that such efforts need also to include the experiences of DMOs and best practices in developing event portfolios. Over time, improvements need to be made based on lessons learnt not only from the other events in the portfolio but also from events held in previous years and elsewhere in the world. As observed by Todd et al. (2017, p.495) successful events "cannot be created and managed purely through planning efforts”.

\subsection{Limitations and final observations}

In the light of the foregoing discussion, it is important to recognise that any study is naturally limited by the data is had available to work with (Gómez-Déniz and Pérez-Rodríguez, 2018). Given the dataset used in this study, it is only capable of offering limited insights with regard to visitors' motivations and other psychological characteristics that might affect their expenditure. Perceived event value and the degree of attendee involvement are additional aspects of the event portfolio that should be considered in further studies (Xu et al., 2016). Future studies would also do well to explore the determinants of repeat attendance and loyalty (Lee et al., 2015).

It is also important to note that the study found that visitors travelling to Madeira expressly to attend the events spent above average but at the same time represented a minority of survey respondents. Developing loyalty will therefore be a critical factor affecting the performance of the portfolio, and the individual events within it, over time. This requires a greater understanding of repeat visits' expectations and needs, which was beyond the scope of this study. It can be noted, even so, that respondents travelling to the destination specifically to attend an event were more inclined to give positive feedback in the survey (91.2\% vs. 77.8\%; $\chi^{2}=70.983$; sig=0.000). This may, in itself, be considered a good outcome in terms visitors 
giving positive world-of-mouth and for this to generate revenue from new visitors in the future. The simple fact that visitors are staying in the destination, occupying in rooms that would otherwise be empty, may also be considered a success, regardless of how much money they spend.

With regard to strategic efforts to attract visitors with higher income, this study suggest that it would be prudent to target older market segments. As the average event visitor is 54 years old, attention should be paid to ensure that the needs of the elderly visitor are met. Previous research has shown, for example, that higher levels of expenditure do occur when visitors perceive there to be convenient shopping opportunities (Pulido-Fernández et al., 2018), as well as convenience and comfort in terms of urban transport systems. In this respect, it is important to bear in mind that any portfolio strategy involving events will need to include stakeholders from outside the events sector, no doubt including accommodation businesses, transport providers, public authorities, and so on. Ziakas (2020), for example, argues that lengthening visitor stays, and increasing total expenditure based on this, will require the development of pre-event and/or post-event opportunities that are attractive to event attendees who want to spend more time together experiencing the wider destination offer. This could involve the bundling (or joint-ticketing) of the event with pre- and post-event activities or tours (Green, 2001; Hiller, 2006). Alternative, the DMO could co-ordinate a bundling strategy that mixes event attendance with key destination attractions (Chalip and McGuirty, 2004).

While the data collection for this paper took place before the Covid-19 pandemic of 2020-21, brief discussion of the implications for the findings of this study is clearly warranted before closing. On the one hand, the pandemic is causing considerable turbulence in the tourism markets at the present time. Madeira is responding to that turbulence, for example by rescheduling the Flower Festival from the spring to the autumn of 2020, to reflect the tightening and relaxation of global travel regulations, and the translation of the Carnival online, rebranding it under the slogan of "Always Carnival”. Such responses tend to be tactical. In the medium term, however, strategic realignment to the 'new normal', as it emerges, may be possible. The findings of this study will undoubtedly be useful to the agencies at that time.

It might also be argued, on the other hand, that the characteristics of Madeira as a tourism destination may serve it well as the global tourism industry begins to recover from the Covid19 pandemic. Indeed, there are indications that tourist behaviour is increasingly favouring travel to more peripheral places, particularly islands where the virus is more easily contained, and to spend more time in one destination rather than to take multiple short holidays. Further developing its strategic event portfolio to bridge periods that are currently free of major events will surely assist Madeira in capturing this market and the findings of this study represent the means by which this can best be achieved.

\section{References}

Abbruzzo, A., Brida, J. G., and Scuderi, R. (2014). Scad-elastic net and the estimation of individual tourism expenditure determinants. Decision Support Systems, 66: 52-60.

Alegre, J., and Cladera, M. (2010) Tourist expenditure and quality: Why repeat tourists can spend less than first-timers. Tourism Economics 16(3): 517-533.

Alegre, J., and Juaneda, C. (2006) Destination loyalty: Consumers' economic behaviour. Annals of Tourism Research 33(3): 684-706. 
Alrawadieh, Z., Alrawadieh, Z., and Kozak, M. (2018) Exploring the impact of tourist harassment on destination image, tourist expenditure, and destination loyalty. Tourism Management 73: 13-20.

Anda, A., Simon, B., Soós, G., Menyhárt, L., Silva, J., and Kucserka, T. (2018) Extending class: A pan evaporation for a shallow lake to simulate the impact of littoral sediment and submerged macrophytes: A case study for Keszthely Bay (Lake Balaton, Hungary). Agricultural and Forest Meteorology (250-251): 277-289.

Antchak, V. (2017) Portfolio of major events in Auckland: Characteristics, perspectives and issues. Journal of Policy Research in Tourism, Leisure and Events 9(3): 280-297.

Antchak, V., and Pernecky, T. (2017) Major events programming in a city: Comparing three approaches to portfolio design. Event Management 21(5): 545-561.

Assaf, A. G., Tsionas, M., and Tasiopoulos, A. (2019). Diagnosing and correcting the effects of multicollinearity: Bayesian implications of ridge regression. Tourism Management, 71: 18.

Barquet, A., Brida, J. G., Osti, L., and Schubert, S. (2011) An analysis of tourists’ expenditure on winter sports events through the tobit censorate model. Tourism Economics 17(6): 1197-1217.

Brida, J., Disegna, M., and Osti L. (2013a) Visitors' expenditure behaviour at cultural events: The case of Christmas markets. Tourism Economics 19(5): 1173-1196.

Brida, J., Disegna, M., Osti, L., (2013b) The effect of authenticity on visitors' expenditure at cultural events. Current Issues in Tourism 16(3): 266-285

Brida, J. G., Meleddu, M., and Pulina, M. (2013c) Factors influencing length of stay of cultural tourists. Tourism Economics 19(6): 1273-1292.

Brida, J., Lanzilotta, B., Moreno, L., and Santiñaque, F. (2018) A non-linear approximation to the distribution of total expenditure distribution of cruise tourists in Uruguay. Tourism Management 69: 62-68.

Brida, J., and Scuderi, R. (2013) Determinants of tourist expenditure: A review of microeconometric models. Tourism Management Perspectives 6: 28-40.

Buning, R., Cole, Z., and McNamee, J. (2016) Visitor expenditure within a mountain bike event portfolio: Determinants, outcomes, and variations. Journal of Sport and Tourism 20(2): 103-122.

Buning, R., and Gibson, H., (2015) The evolution of active-sport-event travel careers. Journal of Sport Management 29(5): 555-569.

Cai, L. (1998) Analyzing household food expenditure patterns on trips and vacations: A Tobit model. Journal of Hospitality and Tourism Research 22(4): 338-358.

Cai, L. (1999) Relationship of household characteristics and lodging spending patterns on leisure trips, Journal of Hospitality and Leisure Marketing 6(2): 5-18.

Cai, L., Hong, G.S., and Morrison, A. (1995) Household expenditure patterns for tourism products and services. Journal of Travel and Tourism Marketing 4(4): 115-140.

Cannon, T. F., and Ford, J. (2002) Relationship of demographic and trip characteristics to visitor spending: An analysis of sports travel visitors across time. Tourism Economics 8(3): 263-271. 
Cárdenas-García, P. (2012) Tourism as an economic development tool: An analysis of key factors. PhD Thesis. University of Jaén, 0953/363.

Carlsen, J., and Wood, D. (2004) Assessment of the economic value of recreation and tourism in Western Australia's national parks, marine parks and forests. Collaborative Research Centre for Sustainable Tourism: Gold Coast.

Catlin, J., Jones, T., Norman, B., and Wood, D. (2010) Consolidation in a wildlife tourism industry: The changing impact of whale shark tourist expenditure in the Ningaloo Coast Region. International Journal of Tourism Research 12: 134-148.

Chalip, L. (2004) Beyond impact: A general model for sport event leverage. In Ritchie, B. W. and Adair, D. (Eds) Sport tourism: Interrelationships, impacts and issues (pp. 226-252). Clevedon: Channel View.

Chalip, L., and Costa., C. (2005) Sport event tourism and the destination brand: Towards a general theory, Sport in Society 8(2): 218-237.

Chalip, L., and Leyns, A. (2002) Local business leveraging of a sport event: Managing an event for economic benefit. Journal of Sport Management 16(2): 132-158.

Chalip, L., and McGuirty, J. (2004) Bundling sport events with the host destination. Journal of Sport and Tourism 9(3): 267-282.

Chang J, (2006) Segmenting tourists to aboriginal cultural festivals: An example in the Rukai Tribal Area, Taiwan. Tourism Management 27: 1224-1234.

Chang, K., Chen, C., and Meyer, T. (2013) A comparison study of travel expenditure and consumption choices between first-time and repeat visitors. Tourism Management 35: 275277.

Chen, C., and Chang, K. (2012) The influence of travel agents on travel expenditures. Annals of Tourism Research 39(2): 1258-1263.

Chen, J., Chang, L., and Cheng, J. (2010) Exploring the market segments of farm tourism in Taiwan. Journal of Hospitality Marketing and Management 19(4): 309-325.

Chhabra, D., Sills, E., and Rea, P. (2002) Tourist expenditures at heritage festivals, Event Management 7(4): 221-230.

Clark, R., and Misener, L. (2015) Understanding urban development through a sport events portfolio: A case study of London, Ontario. Journal of Sport Management 29: 11-26.

Correia, A., Kozak, M., and Gonçalves, F. (2018) Why do tourists spend extravagantly in Portugal? A binary logistic regression by quartiles. Tourism Planning and Development 15(4): 458-472.

Dearden, P., Bennett, M., and Rollins, R. (2006) Diver specialization in Phuket, Thailand: Implications for reef conservation. Environmental Conservation 33(4): 353-363.

Dickson, G., Milne, S., and Werner, K. (2018) Collaborative capacity to develop an events portfolio within a small island development state: The Cook Islands. Journal of Policy Research in Tourism, Leisure and Events 10(1): 69-89.

Disegna, M., and Osti, L., (2016) Tourists’ expenditure behaviour: the influence of satisfaction and the dependence of spending categories. Tourism Economics 22(1): 5-30.

Dredge, D., and Jamal, T. (2015) Progress in tourism planning and policy: A post-structural perspective on knowledge production. Tourism Management 51, 285-297. 
Dredge, D., and Whitford, M. (2011) Event tourism governance and the public sphere, Journal of Sustainable Tourism 19(4/5): 479-499.

Elith, J., Leathwick, J.R., and Hastie, T. (2008) Boosted regression trees: A new technique for modelling ecological data. Journal of Animal Ecology 77: 803-813.

Eugenio-Martin, J., and Inchausti-Sintes, F. (2016) Low-cost travel and tourism expenditures. Annals of Tourism Research 57: 140-159.

Ferdinand, N., and Williams, N. (2013) International festivals as experience production systems. Tourism Management 34: 202-210.

Friedman, J. (2001) Greedy function approximation: A gradient boosting machine. Annals of Statistics 29: 1189-1123.

García-Sánchez, A, Fernández-Rubio, E, and Collado, M. (2013) Daily expenses of foreign tourists, length of stay and activities: Evidence from Spain. Tourism Economics 19(3): 613630.

Gerritsen, D., and van Olderen, R. (2020) Event as a strategic marketing tool. Wallingford: CAB International.

Getz, D., Anderson, D., and Sheehan, L. (1998) Roles, issues and strategies for convention and visitors bureaux in destination planning and product development: A survey of Canadian bureau. Tourism Management 19(4): 331-340.

Getz, D., and McConnell, A. (2014) Comparing trail runners and mountain bikers:

Motivation, involvement, portfolios, and event-tourist careers. Journal of Convention and Event Tourism 15(1): 69-100.

Gibson, H., Kaplanidou, K., and Kang, S. (2012) Small-scale event sport tourism: A case study in sustainable tourism. Sport Management Review 15(2): 160-170.

Godbey, G., and Graefe, A. (1991) Repeat tourism, play and monetary spending. Annals of Tourism Research 18: 213-225.

Gómez-Déniz, E., and Pérez-Rodríguez, J. (2019) Modelling bimodality of length of tourist stay. Annals of Tourism Research 75: 131-151.

Grasgruber, P., Sebera, M., Hrazdíra, E., Cacek, J., and Kalina, T. (2016) Major correlates of male height: A study of 105 countries. Economics and Human Biology 21(May): 172-195.

Green, B. (2001) Leveraging subculture and identity to promote sport events. Sport Management Review 4(1): 1-19

Guo, P., Zeng, F., Hu, X., Zhang, D., Zhu, S., and Deng, Y. (2015) Improved variable selection algorithm using a LASSO-type penalty, with an application to assessing Hepatitis B infection relevant factors in community residents. PLOS ONE 10(7): e0134151.

Hammami, D., Taha, L., Ouarda, L., and Lee, J. (2012) Predictor selection for downscaling GCM data with LASSO. Journal of Geophysical Research Atmospheres 117(D17): 1-11.

Hiller, H. (2006) Post-event outcomes and the post-modern turn: The Olympics and urban transformations. European Sport Marketing Quarterly 6: 317-332.

Hjalager, A.-M., and Kwiatkowski, G. (2017) Entrepreneurial implications, prospects and dilemmas in rural festivals. Journal of Rural Studies 263: 217-228.

Hung, W. T., Shang, J. K., and Wang, F. (2012) Another look at the determinants of tourism expenditure. Annals of Tourism Research 39(1): 495-498. 
Jang, S., Bai, B., Hong, G., and O’Leary, J. (2004) Understanding travel expenditure patterns: A study of Japanese pleasure travelers to the United States by income level. Tourism Management 25(3): 331-341.

Jang, S., and Ham, S. (2009) A double-hurdle analysis of travel expenditure: Baby boomer seniors versus older seniors. Tourism Management 30(3): 372-380.

Jang, S., Ismail, J, and Ham, S., (2002) Heavy spenders, medium spenders, and light spenders of Japanese outbound pleasure travelers. Journal of Hospitality and Leisure Marketing 9(3/4): 83-106.

Jingwen, W., and Mingzhu, L. (2018) Characteristics of visitor expenditure in Macao and their impact on its economic growth. Tourism Economics 24(2): 218-233.

Jones, T., Wood, D., Catlin, J., and Norman, B. (2009) Expenditure and ecotourism:

Predictors of expenditure for whale shark tour participants. Journal of Ecotouris, 8(1): 32-50.

Kelly, D., and Fairley, S. (2018) What about the event? How do tourism-leveraging strategies affect small-scale events? Tourism Management 64: 335-345.

Kim, S., Han, H., and Chon, K. (2008) Estimation of the determinants of expenditures by festival visitors. Tourism Analysis 13(4): 387-400.

Kim, S. S., Prideaux, B., and Chon, K. (2010) A comparison of results of three statistical methods to understand the determinants of festival participants' expenditures. International Journal of Hospitality Management 29(2): 297-307.

Kozak, M., Gokovali, U., and Bahar, O. (2008) Estimating the determinants of tourist spending: A comparison of four models. Tourism Analysis 13(2): 143-155.

Lawson, R. (1994) Demographic segmentation. In Witt, S. F., and Moutinho, L. (Eds) Tourism, marketing and management handbook, 2nd ed. (pp. 311-315). New York: Prentice Hall,

Lee, C., and Taylor, T. (2005) Critical reflections on the economic impact assessment of a mega-event: The case of 2002 FIFA World Cup. Tourism Management 26: 565-603.

Lee, S., Lee, W., Funk, D., and Jordan, J. (2015) Analysis of attendees' expenditure patterns to recurring annual events: Examining the joint effects of repeat attendance and travel distance. Tourism Management 46: 177-186.

Lehto, X., O’Leary, J., and Morrison, A. (2004) The effect of prior experience on vacation behavior. Annals of Tourism Research 31(4): 801-818.

Lew, A., and Ng, P. (2012) Using quantile regression to understand visitor spending. Journal of Travel Research 51(3): 278-288.

Lindberg, K., and Fredman. P. (2015) Uncertainty, data treatment, and the measurement of outdoor recreation expenditure. Journal of Outdoor Recreation and Tourism 12: 99-107.

Marcussen, C. (2011) Determinants of spending by Danish travellers. Anatolia 22(1): 47-55.

Mariani, M., and Giorgio, L. (2017) The 'Pink Night' festival revisited: Meta-events and the role of destination partnerships in staging event tourism. Annals of Tourism Research 62: 89109.

Marrocu, E., Paci, R., and Zara, A. (2015) Micro-economic determinants of tourist expenditure: A quantile regression approach. Tourism Management 50: 13-30. 
Masiero, L., and Nicolau, L. (2012) Tourism market segmentation based on price sensitivity. Journal of Travel Research, 51(4): 426-435.

Matijová, M., Onuferová, E., Rigelský, M., and Stanko, V. (2019). Impact of selected indicators of tourism capacity and performance in the context of the unemployment rate in Slovakia. Journal of Tourism and Services, 10(19): 1-23.

McCartney, G., and Osti, L. (2007) From cultural events to sport events: A case study of cultural authenticity in the dragon boat races. Journal of Sport Tourism 12(1): 25-40.

Meng, F., and Xu, Y. (2012) Tourism shopping behavior: Planned, impulsive, or experiential? International Journal of Culture, Tourism and Hospitality Research 6(3): 250265.

Mihalic T. (2002) Tourism and economic development issues. In Sharpley R, and Telfer D. J. (Eds). Tourism and Development: Concepts and Issues (pp. 81-111). Clevedon: Channel View.

Misener, L., and Mason, D. (2006) Developing local citizenship through sporting events: Balancing community involvement and tourism development. Current Issues in Tourism 9(45): 384-398.

Mok, C., and Iverson, T. (2000) Expenditure-based segmentation: Taiwanese tourists to Guam. Tourism Management 21(3): 299-305.

Mortazavi, R. (2021) The relationship between visitor satisfaction, expectation and spending in a sport event. European Research on Management and Business Economics 27(1): 100132.

O’Brien, D., and Chalip, L. (2008) Sport events and strategic leveraging: Pushing towards the triple bottom line. In Woodside, A., and Martin, D. (Eds) Tourism management: Analysis, behaviour and strategy (pp. 318-338). Wallingford: CAB International

O’Brien, D. (2007) Points of leverage: maximizing host community benefit from a regional surfing festival. European Sport Management Quarterly 7(2): 141-165.

Oloritun, R., Ouarda, T., Moturu, S., Madan, A., Pentland, A., and Khayal, I. (2013) Change in BMI accurately predicted by social exposure to acquaintances. PLoS ONE 8(11): e79238.

Oppermann, M. (1996) Information sources used revisited. Hospitality Research Journal 20(1): 119-122.

Oppermann, M., and Chon, K. (1997) Convention participation decision-making process. Annals of Tourism Research 24(1): 178-191.

Pennington-Gray, L., and Holdnak, A. (2002) Out of the stands and into the community: Using sports events to promote a destination. Event Management 7(3): 177-186.

Pereira, E., Mascarenhas, M., Flores, A., and Pires, G. (2015) Nautical small-scale sports events portfolio: A strategic leveraging approach. European Sport Management Quarterly 15(1): 27-47.

Petrick, J. (2004a) Are loyal visitors desired visitors? Tourism Management 25: 463-470.

Petrick, J. (2004b) First timers’ and repeaters’ perceived value. Journal of Travel Research 43: 29-38.

Phi, G., Dredge, D., and Whitford, M. (2014) Understanding conflicting perspectives in event planning and management using Q method. Tourism Management 40: 406-415. 
Pulido-Fernández, J., Cárdenas-García, P., and Carrillo-Hidalgo, I. (2016) Trip cultural activities and tourism expenditure in emerging urban-cultural destinations. International Journal of Tourism Research 18: 286-296.

Pulido-Fernández, J., and Sánchez-Rivero, M. (2010) Attitudes of the cultural tourist: A latent segmentation approach. Journal of Cultural Economics 34(2): 111-129.

Quan, S., and Wang, N. (2004) Towards a structural model of the tourist experience: An illustration from food experience in tourism. Tourism Management 25(3): 297-305.

Ritchie, B., Mosedale, L., and King, J. (2002) Profiling sport tourists: The case of Super 12 Rugby Union in the Australian Capital Territory, Australia, Current Issues in Tourism 5(1): 33-44.

Ruggieri, G. (2015). Islands tourism seasonality. In Pechlaner, H., and Smeral, E. (Eds) Tourism and leisure: Current issues and perspectives of development (pp. 371-383). Wiesbaden: Springer Gabler.

Saayman, M., and Saayman, A. (2006) Does the location of arts festivals matter for the economic impact? Papers in Regional Science 85(4): 569-584.

Saayman, M., Saayman, A., and du Plessis, C. (2005) Analysis of spending patterns of visitors of three World Cup Cricket matches in Potchefstroom, South Africa. Journal of Sport Tourism 10(3): 211-221.

Sainaghi, R., Mauri, A. G., Ivanov, S., \& d’Angella, F. (2019). Mega events and seasonality: The case of the Milan World Expo 2015. International Journal of Contemporary Hospitality Management 31(1): 61-86.

Salgado-Barandela, J., Barajas, A., and Sánchez-Fernández, P. (2018) Determinants of the spending of sporting tourists: The case of attendees at professional basketball. European Research on Management and Business Economics 24: 168-176.

Santos, C., and Vieira, J., (2012) An analysis of visitors' expenditures in a tourist destination: OLS, quantile regression and instrumental variable estimators. Tourism Economics 18: 555576.

Sato, M., Jordan, J., Kaplanidou, K., and Funk, D. (2014) Determinants of tourists’ expenditure at mass participant sport events: A five-year analysis. Current Issues in Tourism 17: 763-771.

Seiler, V., Hsieh, S., Seiler, M., and Hsieh, C. (2002) Modeling travel expenditures for Taiwanese tourism. Journal of Travel and Tourism Marketing 13(4): 47-60.

Sharma, A., Woodward, R., and Grillini, S. (2020) Unconditional quantile regression analysis of UK inbound tourist expenditures. Economics Letters 186: 108857.

Silva, F., Câmara, G., Vieira, J., and Santos, C. (2020) Is the spending behaviour of tourists affected by low-cost carriers' operation? Some empirical evidence. Tourism Management Perspectives 33: 100630.

Silveira, R., Stergiou, P., Figueiredo, P., Castro, F., Katz, L., and Stefanyshyn, D. (2018) Key determinants of time to $5 \mathrm{~m}$ in different ventral swimming start techniques. European Journal of Sport Science 18(10): 1317-1326.

Smith, S., and Costello, C. (2009) Segmenting visitors to a culinary event: Motivations, travel behavior, and expenditures. Journal of Hospitality Marketing and Management 18(1): 44-67.

STATA, (2019). STATA Base Reference Manual, Release 16, Stata Press, Texas. 
Tanford, S., Montgomery, R., and Hertzman, J. (2012) Towards a model of wine event loyalty. Journal of Convention and Event Tourism 13(2): 77-99.

Tang, Q., and Turco, D. (2001) Spending behaviors of event tourists. Journal of Convention and Exhibition Management 3(2): 33-40.

Thibaut, E., Vos, S., Lagae, W., Puyenbroeck, T., and Scheerder, J. (2016) Participation in cycling, at what cost? Determinants of cycling expenses. International Journal of Sport Management and Marketing 16(3-6): 221-238.

Thrane, C. (2002) Jazz festival visitors and their expenditures: Linking spending patterns to musical interest. Journal of Travel Research 40(3): 281-286.

Thrane, C. (2014) Modeling micro-level tourism expenditure: Recommendations on the choice of independent variables, functional form, and estimation technique. Tourism Economics 20(1): 51-60.

Thrane, C. (2015) Students' summer tourism: An econometric analysis of trip costs and trip expenditures. Tourism Management Perspectives 15: 65-71.

Thrane, C. (2016) The determinants of Norwegians’ summer tourism expenditure: Foreign and domestic trips. Tourism Economics 22(1): 31-46.

Thrane, C., and Farstad, E. (2011) Domestic tourism expenditures: The non-linear effects of length of stay and travel party size. Tourism Management 32: 46-52.

Tibshirani, R. (1996) Regression shrinkage and selection via the lasso. Journal of the Royal Statistical Society: Series B 58(1): 267-288.

Todd, L., Leask, A., and Ensor, J. (2017) Understanding primary stakeholders' multiple roles in hallmark event tourism management. Tourism Management 59: 494-509.

Tyrrell, T., and Johnston, R. (2006) The economic impacts of tourism: A special issue. Journal of Travel Research 45(1): 3-7.

Viol, M., Todd, L., Theodoraki, E., and Anastasiadou, C. (2018). The role of iconic-historic commemorative events in event tourism: Insights from the 20th and 25th anniversaries of the fall of the Berlin Wall. Tourism Management 69: 246-262.

Wang, Y., and Davidson, M. C. G. (2010) Chinese holiday markers expenditure: Implications for marketing and management. Journal of Hospitality Marketing andManagement 19(4): 373-396.

Wang, Y., Rompf, P., Severt, D., and Peerapatdit, N. (2006) Examining and identifying the determinants of travel expenditure patterns. International Journal of Tourism Research, 8(5): 333-346.

White, E., and Stynes, D. (2008) National forest visitor spending averages and the influence of trip type and recreation activity. Journal of Forestry 116(1): 17-24.

Wicker, P., Hallmann, K., and Zhang, J. (2012). What is influencing consumer expenditure and intention to revisit? An investigation of marathon events. Journal of Sport and Tourism 17(3): 165-182.

Wood, D., and Glasson, J. (2006) Giving the environment a voice: the transformational potential of valuing tourism in sensitive natural environments: The case of the Ningaloo Coastal region, Western Australia. Journal of Planning Practice and Research 20(4): 391407. 
Wood, D., Glasson, J., Carlsen, J., and Hopkins, D. (2006) Economic evaluation of tourism for natural areas: Development of a 'Toolkit Approach', Gold Coast, Australia. STCRC Monograph.

Wu, L., Zhang, J., and Fujiwara, A. (2013) Tourism participation and expenditure behaviour: Analysis using a scobit based discrete-continuous choice model. Annals of Tourism Research 40: $1-17$.

Xu, Y., Wong, I., and Tan, X. (2016) Exploring event bundling: The strategy and its impacts. Tourism Management 52: 455-467.

Yoon, Y., Lee, J., and Lee, C. (2010) Measuring festival quality and value affecting visitors' satisfaction and loyalty using a structural approach. International Journal of Hospitality Management 29: 335-342.

Ziakas, V. (2014) Planning and leveraging event portfolios: Towards a holistic theory. Journal of Hospitality Marketing and Management 23(3): 327-356.

Ziakas, V. (2019) Embracing the event portfolio paradigm in academic discourse and scholarship. Journal of Policy Research in Tourism, Leisure and Events 11(sup1): s27-s33.

Ziakas, V. (2020) Leveraging sport events for tourism development: The event portfolio perspective. Journal of Global Sport Management, DOI: 10.1080/24704067.2020.1731700

Ziakas, V., and Costa, C. (2011) Events portfolio and multi-purpose development: Establishing the conceptual grounds. Sport Management Review 14(4): 409-423.

Ziakas, V., and Getz, D. (2021) Event portfolio management: An emerging transdisciplinary field of theory and praxis. Tourism Management 83: 104233. 
Table 1: Characteristics of events in the portfolio

\begin{tabular}{|c|c|c|c|c|c|}
\hline Event & Location & Timing & Description & Notes & Website \\
\hline Carnival & Funchal & $\begin{array}{l}\text { Annually. } \\
40 \text { days of } \\
\text { Lent in the } \\
\text { approach to } \\
\text { Easter }\end{array}$ & $\begin{array}{l}\text { Includes two main } \\
\text { parades through } \\
\text { Funchal. Various } \\
\text { fringe activities also } \\
\text { take place in private } \\
\text { homes }\end{array}$ & $\begin{array}{ll}\text { - } & \text { Considered a } \\
& \text { hallmark } \\
\text { event } & \text { Strong } \\
\text { international } \\
\text { orientation } \\
\text { - } & \text { Also a local } \\
\text { cultural } \\
\text { emphasis }\end{array}$ & $\begin{array}{l}\text { http://www.visit } \\
\text { madeira.pt/en- } \\
\text { gb/resultados- } \\
\text { de- } \\
\text { pesquisa/resulta } \\
\text { dos-pesquisa- } \\
\text { detalhe/always- } \\
\text { carnival- } \\
\text { madeira }\end{array}$ \\
\hline $\begin{array}{l}\text { Flower } \\
\text { Festival }\end{array}$ & Funchal & $\begin{array}{l}\text { Annually } \\
\text { after } \\
\text { Easter. } \\
\text { Lasts for } \\
\text { three weeks }\end{array}$ & $\begin{array}{l}\text { Funchal's streets are } \\
\text { carpeted with flowers. } \\
\text { Culminates in a parade } \\
\text { with dozens of floats } \\
\text { decorated with the } \\
\text { depictions of local } \\
\text { traditions }\end{array}$ & 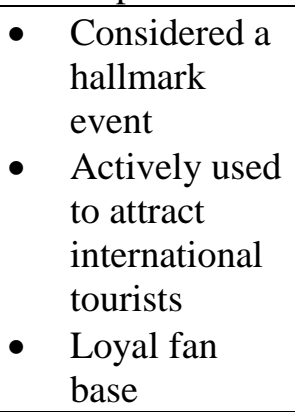 & $\begin{array}{l}\text { http://www.visit } \\
\text { madeira.pt/en- } \\
\text { gb/what-to- } \\
\text { do/events/search } \\
\text { /flower-festival }\end{array}$ \\
\hline $\begin{array}{l}\text { Atlantic } \\
\text { Festival }\end{array}$ & Funchal & $\begin{array}{l}\text { Annually in } \\
\text { June. Lasts } \\
\text { for one } \\
\text { month }\end{array}$ & $\begin{array}{l}\text { Covers a range of } \\
\text { initiatives including } \\
\text { pyrotechnic-musical } \\
\text { shows, musical } \\
\text { performances and a } \\
\text { regional arts week. }\end{array}$ & $\begin{array}{ll}\text { - } & \text { Considered a } \\
\text { niche event } \\
\text { - } & \text { International } \\
\text { audience }\end{array}$ & $\begin{array}{l}\text { http://www.visit } \\
\text { madeira.pt/en- } \\
\text { gb/what-to- } \\
\text { do/events/search } \\
\text { /atlantic-festival }\end{array}$ \\
\hline $\begin{array}{l}\text { Wine } \\
\text { Festival }\end{array}$ & $\begin{array}{l}\text { Funchal } \\
\text { and } \\
\text { Camara } \\
\text { de Lobos }\end{array}$ & $\begin{array}{l}\text { Annually. } \\
\text { September. } \\
\text { Lasts for } \\
\text { two weeks }\end{array}$ & $\begin{array}{l}\text { Celebrates the } \\
\text { tradition of Madeira } \\
\text { Wine. Main event in } \\
\text { Funchal includes } \\
\text { musical performances, } \\
\text { exhibitions and a } \\
\text { European folklore } \\
\text { week. A wine harvest } \\
\text { festival takes place in } \\
\text { nearby Camara de } \\
\text { Lobos }\end{array}$ & $\begin{array}{ll}\text { - } & \text { Considered a } \\
\text { niche event } \\
\text { - } & \text { Strong } \\
\text { international } \\
\text { orientation } \\
\text { - } & \text { Also a local } \\
\text { cultural } \\
\text { emphasis }\end{array}$ & $\begin{array}{l}\text { http://www.visit } \\
\text { madeira.pt/en- } \\
\text { gb/what-to- } \\
\text { do/events/search } \\
\text { fmadeira-wine- } \\
\text { festival }\end{array}$ \\
\hline $\begin{array}{l}\text { Christmas } \\
\text { and } \\
\text { New } \\
\text { Year's } \\
\text { Eve }\end{array}$ & Funchal & $\begin{array}{l}\text { Annual. } \\
\text { December } \\
\text { and early } \\
\text { January. } \\
\text { Lasts five } \\
\text { weeks. }\end{array}$ & $\begin{array}{l}\text { Includes a world- } \\
\text { famous firework show, } \\
\text { decorative lights on } \\
\text { the streets and a varied } \\
\text { programme of cultural, } \\
\text { religious, ethnic and } \\
\text { artistic sub-events that } \\
\text { are deeply rooted in } \\
\text { local identity and } \\
\text { cultural traditions. }\end{array}$ & $\begin{array}{ll}\text { - } & \text { Considered a } \\
\text { hallmark } \\
\text { event } \\
\text { - } & \text { Strong } \\
\text { international } \\
\text { orientation } \\
\text { - } & \text { Mild weather } \\
\text { also a selling } \\
\text { point } \\
\text { - Also a local } \\
\text { cultural } \\
\text { emphasis } \\
\end{array}$ & $\begin{array}{l}\text { http://www.visit } \\
\text { madeira.pt/en- } \\
\text { gb/what-to- } \\
\text { do/events/search } \\
\text { /christmas-and- } \\
\text { new- } \\
\text { year\%C2\%B4s- } \\
\text { eve-festivities }\end{array}$ \\
\hline
\end{tabular}


Table 2: Key survey statistics

\begin{tabular}{|c|c|c|c|c|c|c|}
\hline & Carnival & Flower & Atlantic & Wine & $\begin{array}{l}\text { Christmas and } \\
\text { New Year }\end{array}$ & Average \\
\hline Percentage of sample & $19 \%$ & $20 \%$ & $21 \%$ & $11 \%$ & $29 \%$ & \\
\hline \multicolumn{7}{|l|}{ Socio-demographic data } \\
\hline Age: & 57 years & 61 years & 56 years & 54 years & 57 years & 58 years \\
\hline $25-34$ & $7 \%$ & $6 \%$ & $8 \%$ & $12 \%$ & $9 \%$ & $8 \%$ \\
\hline 65 and + & $35 \%$ & $41 \%$ & $30 \%$ & $23 \%$ & $34 \%$ & $34 \%$ \\
\hline \multicolumn{7}{|l|}{ Gender: } \\
\hline Male & $55 \%$ & $47 \%$ & $51 \%$ & $50 \%$ & $51 \%$ & $51 \%$ \\
\hline Female & $45 \%$ & $53 \%$ & $49 \%$ & $50 \%$ & $49 \%$ & $49 \%$ \\
\hline \multicolumn{7}{|l|}{ Civil status: } \\
\hline Married & $73 \%$ & $75 \%$ & $71 \%$ & $74 \%$ & $67 \%$ & $72 \%$ \\
\hline Income & 4031 & 3234 & 3342 & 3560 & 3541 & 3531 \\
\hline$<€ 1000$ & $5.60 \%$ & $7.40 \%$ & $8.00 \%$ & $5.90 \%$ & $6.00 \%$ & $6.60 \%$ \\
\hline$>€ 7500$ & $8.70 \%$ & $2.90 \%$ & $4.70 \%$ & $5.30 \%$ & $6.00 \%$ & $5.50 \%$ \\
\hline \multicolumn{7}{|l|}{ Academic background } \\
\hline Secondary education & $41.16 \%$ & $37.59 \%$ & $37.79 \%$ & $43.32 \%$ & $40.51 \%$ & $39.80 \%$ \\
\hline Undergraduate degree & $18.81 \%$ & $10.68 \%$ & $14.05 \%$ & $15.73 \%$ & $14.51 \%$ & $14,59 \%$ \\
\hline $\mathrm{PhD} /$ Masters & $4.34 \%$ & $5.71 \%$ & $5.85 \%$ & $7.12 \%$ & $5.92 \%$ & $5.68 \%$ \\
\hline \multicolumn{7}{|l|}{ Nationality } \\
\hline British & $37 \%$ & $20 \%$ & $26 \%$ & $28 \%$ & $26 \%$ & $27 \%$ \\
\hline German & $29 \%$ & $20 \%$ & $21 \%$ & $19 \%$ & $22 \%$ & $23 \%$ \\
\hline Portuguese & $8 \%$ & $18 \%$ & $12 \%$ & $10 \%$ & $17 \%$ & $14 \%$ \\
\hline French & $8 \%$ & $17 \%$ & $15 \%$ & $15 \%$ & $10 \%$ & $13 \%$ \\
\hline Other & $18 \%$ & $25 \%$ & $25 \%$ & $28 \%$ & $25 \%$ & $24 \%$ \\
\hline \multicolumn{7}{|l|}{ Travel arrangements and motivation } \\
\hline Motivation to travel & $13 \%$ & $42 \%$ & $4 \%$ & $3 \%$ & $47 \%$ & $26 \%$ \\
\hline Length of stay & 9.8 days & 8.1 days & 7.8 days & 8.5 days & 9.4 days & 8.9 days \\
\hline Travel party & 2.34 persons & 2.91 persons & 2.99 persons & 2.76 persons & 2.75 persons & 2.75 persons \\
\hline First visit to Madeira & $51 \%$ & $58 \%$ & $64 \%$ & $63 \%$ & $45 \%$ & $55 \%$ \\
\hline Previous knowledge & $59 \%$ & $80 \%$ & $39 \%$ & $45 \%$ & $78 \%$ & $64 \%$ \\
\hline \multicolumn{7}{|l|}{ Behaviour and satisfaction } \\
\hline Average expenditure & $€ 2612$ & $€ 2933$ & $€ 2700$ & $€ 2538$ & $€ 2996$ & $€ 2795$ \\
\hline Daily expenditure & $€ 266.50$ & $€ 364.40$ & $€ 345.60$ & $€ 298.70$ & $€ 318.70$ & $€ 321$ \\
\hline Daily expenditure by person & $€ 133.30$ & $€ 125.20$ & $€ 115.40 €$ & $€ 108.30$ & $€ 115.80$ & $€ 120$ \\
\hline Participation in the main event & $76 \%$ & $84 \%$ & $81 \%$ & $52 \%$ & $93 \%$ & $80 \%$ \\
\hline Participation in other events & $8.20 \%$ & $6.30 \%$ & $4.70 \%$ & $6.80 \%$ & $20.30 \%$ & $10.50 \%$ \\
\hline Satisfaction & 5.7 & 6.2 & 5.8 & 5.6 & 6.3 & 6.0 \\
\hline Willingness to recommend & $79 \%$ & $87 \%$ & $73 \%$ & $62 \%$ & $91 \%$ & $81 \%$ \\
\hline Percentage of comments, positive & $5.00 \%$ & $5.40 \%$ & $7.40 \%$ & $6,50 \%$ & $9,20 \%$ & $6,90 \%$ \\
\hline Percentage of comments, negative & $10.30 \%$ & $23.00 \%$ & $17.10 \%$ & $18.70 \%$ & $10.90 \%$ & $15.40 \%$ \\
\hline Percentage of comments, lack of information & $9.30 \%$ & $9.30 \%$ & $10.50 \%$ & $10.40 \%$ & $1.70 \%$ & $6.50 \%$ \\
\hline
\end{tabular}


Table 3: t-tests and correlation: Impact on expenditure (total sample)

\begin{tabular}{|c|c|c|c|}
\hline Variables & Average & $\mathrm{t}$ & Sig. \\
\hline Gender (male vs. female) & $€ 2856$ vs. €2731 & 1.795 & 0.073 \\
\hline Nationality: British & $€ 2757$ vs. €2896 & -1.82 & 0.069 \\
\hline Nationality: German & $€ 2789$ vs. €2814 & -0.336 & 0.737 \\
\hline Nationality: Portuguese & $€ 2935$ vs. €1912 & 13.499 & 0.000 \\
\hline Nationality: French & $€ 2773$ vs. $€ 2948$ & -1.496 & 0.135 \\
\hline Civil status: Married & $€ 2584$ vs. $€ 2877$ & -3.548 & 0.000 \\
\hline Motivation & $€ 2767$ vs. $€ 2872$ & -1.331 & 0.183 \\
\hline First visit & $€ 2824$ vs. $€ 2770$ & 0.781 & 0.435 \\
\hline Previous participation & $€ 2757$ vs. €2958 & -2.204 & 0.028 \\
\hline Previous knowledge & $€ 2724$ vs. €2835 & -1.551 & 0.121 \\
\hline Highly satisfied & $€ 2704$ vs. €2937 & -3.199 & 0.001 \\
\hline Income $*$ Expenditure & $\mathrm{r}=0.284$ & $\ldots$ & 0.000 \\
\hline Satisfaction * Expenditure & $r=0.044$ & $\ldots$ & 0.013 \\
\hline
\end{tabular}


Table 4: Basic statistics on the LASSO procedure

\begin{tabular}{|c|c|c|c|c|c|c|c|c|}
\hline Method & lambda & $\begin{array}{c}\text { No. non-zero } \\
\text { coefficients }\end{array}$ & No. variables & $\begin{array}{c}\text { Out-of-sample } \\
\text { squared }\end{array}$ & In-sample squared & BIC & $\cdots$ & \\
\hline CV & 37.0917 & 22 & 50 & 0.2948 & & & \\
\hline Adaptive & 30.48316 & 17 & 50 & 0.3038 & & \\
\hline Plugin & .1015833 & 6 & 50 & $\cdots$ & 0.2227 & 0.2227 & \\
\hline
\end{tabular}

\begin{tabular}{|c|c|c|c|}
\hline Method and sample & MSE & R-squared & Obs \\
\hline \multicolumn{4}{|l|}{ Linearcv1 } \\
\hline Training & 2494346 & 0.3380 & 1558 \\
\hline Testing & 2883510 & 0.2236 & 1559 \\
\hline \multicolumn{4}{|l|}{ Adaptive1 } \\
\hline Testing & 2896871 & 0.2200 & 1559 \\
\hline \multicolumn{4}{|l|}{ Plug-in } \\
\hline Training & 2614886 & 0.3056 & 1559 \\
\hline Testing & 2958808 & 0.2033 & 1559 \\
\hline
\end{tabular}


Table 5: Results of the LASSO model, with corresponding OLS and Tobit results for the purposes of comparison

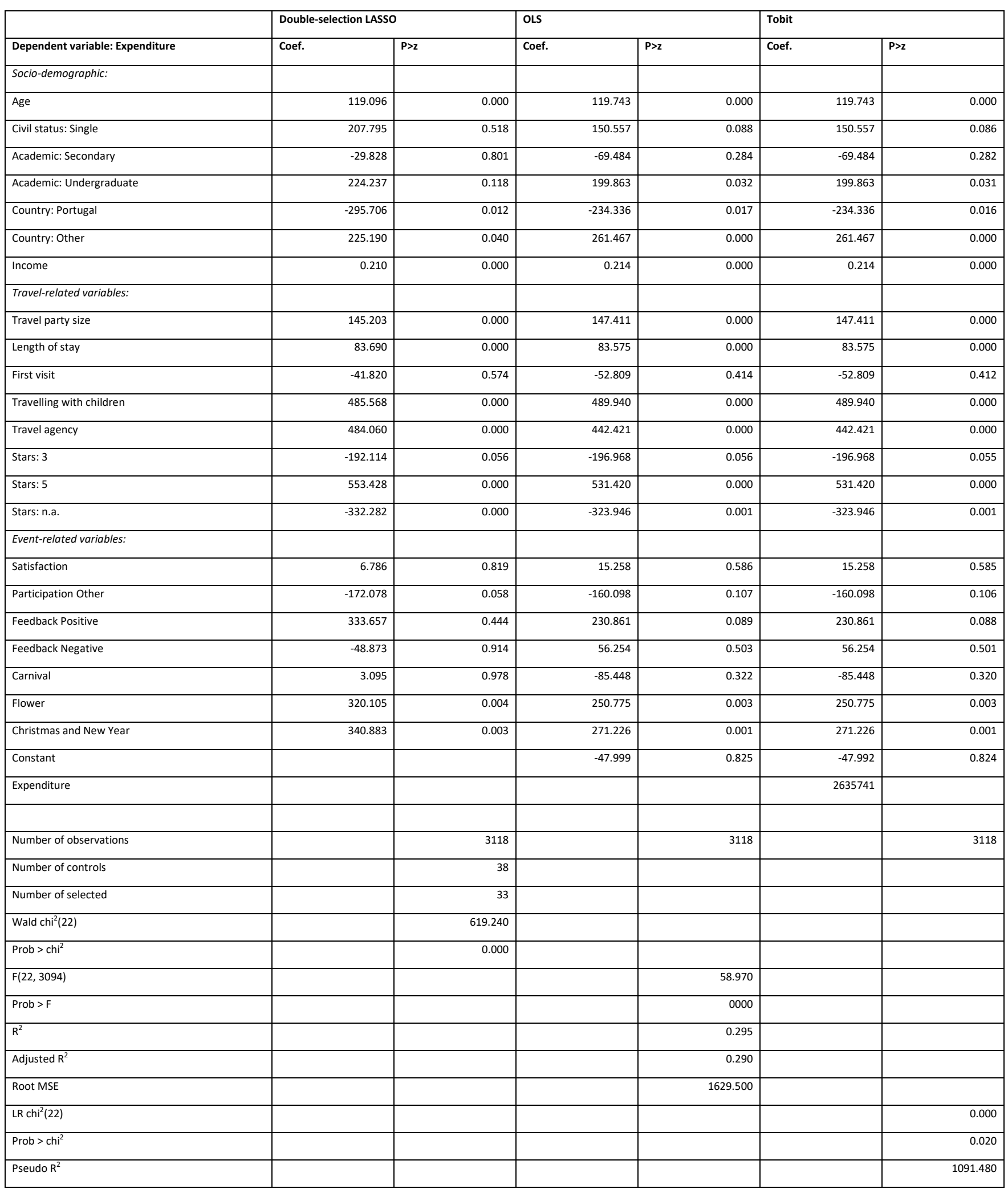


Table 6: Final OLS/Tobit results across the five events

\begin{tabular}{|c|c|c|c|c|c|c|}
\hline & $\begin{array}{l}\text { Overall } \\
\text { Sample }\end{array}$ & Carnival & Flower & Atlantic & Wine & $\begin{array}{c}\text { Christmas and New } \\
\text { Year }\end{array}$ \\
\hline Travel party size & + & + & + & + & + & + \\
\hline Children & + & n.s. & n.s. & $+(10 \%)$ & n.s. & n.s. \\
\hline Age & + & $+(10 \%)$ & n.s. & n.s. & $+(10 \%)$ & + \\
\hline Income & + & + & + & + & + & + \\
\hline First Visit & n.s. & n.s. & n.s. & n.s. & n.s. & n.s. \\
\hline Length of stay & + & + & + & + & + & + \\
\hline Travel agency & + & $+(10 \%)$ & $+(5 \%)$ & $+(10 \%)$ & n.s. & + \\
\hline Feedback & n.s. & n.s. & n.s. & n.s. & n.s. & n.s. \\
\hline Positive feedback & $+(10 \%)$ & n.s. & n.s. & n.s. & n.s. & n.s. \\
\hline Satisfaction & $+(10 \%)$ & n.s. & n.s. & n.s. & n.s. & $+(5 \%)$ \\
\hline Participation: Other & n.s. & n.s. & n.s. & n.s. & n.s. & n.s. \\
\hline Country: Portugal & $+(5 \%)$ & n.s. & $-(5 \%)$ & n.s. & n.s. & n.s. \\
\hline Country: Other & + & $+(10 \%)$ & n.s. & $+(5 \%)$ & n.s. & + \\
\hline Civil status: Single & $+(10 \%)$ & n.s. & n.s. & n.s. & n.s. & $+(10 \%)$ \\
\hline Academic: Secondary & n.s. & n.s. & n.s. & n.s. & n.s. & n.s. \\
\hline Academic: Undergraduate & $+(5 \%)$ & n.s. & n.s. & n.s. & $+(10 \%)$ & n.s. \\
\hline Stars: 3 & $-(5 \%)$ & n.s. & n.s. & $-(10 \%)$ & $-(10 \%)$ & $-(10 \%)$ \\
\hline Stars: 5 & + & $+(5 \%)$ & + & n.s. & n.s. & + \\
\hline Stars: Local lodging & - & n.s. & $-(10 \%)$ & - & n.s. & n.s. \\
\hline
\end{tabular}

